\title{
Digital Society and Corporate Reputation: Towards the Next Generation of Insights
}

\author{
Sharifah Faridah Syed Alwi ${ }^{1} \cdot$ T. C. Melewar ${ }^{2} \cdot$ Maria Teresa Cuomo $^{3} \cdot$ Manfred Schwaiger $^{4}$
}

Published online: 8 June 2020

(c) Reputation Institute and Springer Nature Limited 2020

Businesses today face a challenging and uncertain environment as digital technology continues to advance. One particular feature of this post-modern era of marketing and technology is the ability of consumers to create and sell their own brands (Olins 2014) in a process sometime known as co-creation (Prahalad et al. 2004). Digital technology has allowed consumer power to rise dramatically, as consumers actively engage and interact in online spaces (Kline et al. 2003; Vargo et al. 2008). Digital technology creates a capacity to "contextualize" information, lifestyles and values, consumer goods, brand content value and interactions between individuals and the product, enabling consumers to identify and define new opportunities where their personal interactions are concerned. Using digital platforms such as Facebook, Twitter, Hashtag and Instagram, consumers from different groups and communities in digital space (Sillence and Baber 2004) can interact across geographical boundaries $24 \mathrm{~h}$ a day, 7 days a week, expressing their enthusiasm or disdain for companies and brands, creating more choices for themselves and ultimately affecting their buying decisions (Hietanen and Rokka 2015).

These groups within digital society are growing in number and influence. Their interactions have turned them into a powerful force with a global platform. Individuals are contacted by other users through geo-localized devices, multimedia content or indications from websites and social networks (Riva 2010). Marketers have come to realize that they no longer have full control or ownership over their own brands (Gensler et al. 2013; Park and Kim 2014). Today,

Sharifah Faridah Syed Alwi

sharifah.alwi@brunel.ac.uk

1 Brunel University London, London, UK

2 Middlesex University London, The Burroughs, London NW4 4BT, UK

3 University of Salerno, Salerno, Italy

4 Ludwig-Maximilians-University Munich, Munich, Germany consumers from certain groups and sections of society are making some decisions that were once the preserve of the boardroom. Since consumers are "self-publishing", where does this leave the multinational corporation? (Belk 2013; Olins 2014).

Answering this question requires detailed understanding of the processes under way on digital platforms, which are now a distinguishing trait of digital society. The detailed discussion and interaction that consumers engage in encompasses everything from instructions about the product displayed in the store, to tagging objects, to noting news that particularly impacts on their perceptions, within a new system of social sense-making (Maitlis et al. 2013).

In other words, technology has transformed not only technical capability but also socializing (Kline et al. 2003). This defines the model of interactive society today-based on the contribution of the community of reference, or word of mouth (WOM; Cova and Cova 2002), and ignoring traditional media platforms that target mass audiences. The whole phenomenon, therefore, requires a redesigning of strategic interest in the creation of interactive and social experiences. This will enhance corporate reputation and consideration (Fombrun and van Riel 1997; Schwaiger 2004; Walker 2010; Melewar et al. 2012; Hamzah et al. 2014).

All of this brings us beyond the era in which businesses focused exclusively on economic value, to a new world where they need to consider how to "create and position a company/brand that conveys a more personal experience yet also shares and embraces the dimensions of company/ brand identity, the feeling for and belonging to a community" (Riva 2010, p. 20). At first glance, corporate reputation seems to have been completely redefined. To survive in this new age, organizations must identify strategies for digital or integrated engagement (Schultz and Block 2011), i.e. they must change their interaction tactics with stakeholders (Raithel and Schwaiger 2015) within a graded scale of persuasion, relationships, experience and sharing (Biraghi and Gambetti 2013; Groß 2015; Kang et al. 2015). Consequently, 
the personalization and exclusivity of the message, timeliness, and the placing and contextualizing of individual experience are already becoming essential elements of media platforms for organizations seeking to reposition themselves.

In our Special Issue, we therefore, address a series of essential questions: What are the critical elements that characterize corporate reputation in the digital era? Who are the members of digital society? How can an organization position itself now? Are we dealing with an innovative construct or merely a hybrid or integrated framework? For example, there are several ongoing discussions about cocreation activity, but what is it and how do we measure it? What is the direction for the future? What conceptual and analytical frameworks are best able to encourage the next generation of insights?

The first article, "The effects of paracrisis origin and response strategy on audience's perceived organizational reputation and behavioral intentions", by Honisch and Manchón, explores the paracrisis in social media issues that needs to be anticipated, identified, monitored and managed with regard to a company's reputation. The authors note that, while PR practitioners already have to deal with this phenomenon on a daily basis, only a few studies have examined paracrisis response strategies for handling reputational threats. In particular, the authors look at four organizational response strategies-reform, use humor, refuse and refute-which are examined in two within-subjects experiments, with self-imposed and external paracrisis origins, respectively, via Facebook. They find that reform is the best strategy by a considerable margin, while strategies using humor are the least effective. The study concludes that, since paracrises are social media crises, organizations should be able to adapt by explaining the situation and exchanging information horizontally. It guides PR practitioners and communication managers on the most suitable strategies for paracrisis management via Facebook, and offers insights on crisis prevention, and consequently managing issues and corporate reputation.

Kelley and Marcelo contribute the second paper of this Special Issue with their paper entitled "IT signal generation and management capabilities' effect on corporate reputation: A typological approach to strategic positioning in a digital world". The authors explore how digital technology strategies affect signal generation capabilities and signal management capabilities when managing corporate reputation. Using signaling theory and the idea of informational asymmetries, they highlight the complementary roles of current IT in managing corporate reputation. They enhance signaling theory by incorporating contemporary technologies into the relationship between a firm's signaling or communication strategy and corporate reputation. The study also introduces a new behavioral classification typology for firms' strategic management, namely, signal amplification, squandering, mollification and diminishment positions, which is contingent on the importance of reputation to firms and tactical approaches from a position- and cost-based perspective. In practical terms, managers are urged to note how new technologies can be used to manage reputation in relation to their needs, and the cost of investing in these technologies. The authors also suggest that companies wishing to compete effectively in a world dominated by the creation and use of information must establish internal capabilities that complement investments in IT and maximize reputational performance for the lowest cost possible. They conclude that managers should recognize this position and decide the right approach to creating and managing contemporary technologies that may be complementary to, or in some cases substitutes for, each other.

The third article, "Why spelling errors matter: Online company reviews and organizational attraction", is by Cooper, Diab and Beeson. They examine the effects on organizational attraction of the quality (e.g. spelling errors vs. no spelling errors) and valence (e.g. positive vs. negative) of online company reviews, by asking 161 participants to imagine they are searching for a job based on four online company reviews. The participants who viewed positive reviews without spelling errors rated general company attractiveness, job pursuit intentions and company prestige more highly than those who viewed positive reviews with spelling errors. The authors also conclude that valence and quality have different effects. For example, the effect of positive online reviews on organizational attraction supports past research suggesting that potential applicants exposed to positive WOM are more attracted to organizations. The study suggests that valence has a stronger effect on potential applicants' attraction to organizations when there are no spelling errors than when there are spelling errors, especially when the review is positive. The authors note that spelling errors do indeed have detrimental effect on perceived credibility.

The fourth article, "Digital word of mouth and organizational attraction: Focusing on message characteristics and time", is contributed by Caudill and Diab. They address the lack of research on how WOM factors influence organizational attraction over time, examining the effects of digital WOM valence, medium and source. In particular, they use third-party influences as drivers of corporate reputation via electronic WOM. They note that, while these influences are typically outside of the control of the company, they are key to reputation-building experience when one pursues a job at a company. Interestingly, they find that the interaction between valence and medium does not hold for job pursuit intentions, but this is not the case for company attractiveness. For example, they conclude that the effect of past employee testimonials does not influence potential job pursuit, which contradicts earlier studies. They note that this finding is somewhat surprising, since people may perceive 
past employees who provide negative WOM as angry or retaliating against their former company. Hence, they conclude that past employees are considered as company-independent sources.

The fifth paper "Does corporate reputation matter? Role of social media in consumer intention to purchase innovative food products", by Balakrishnan and Foroudi, explores how corporate reputation in the food industry is impacted by innovations in every link of the supply chain. The authors note that, although numerous studies have examined food purchase patterns, these were somewhat limited to a generic understanding of innovative food but individual purchasing behavior. They point out that understanding this area will benefit social and individual orientation in consumer purchase behavior. They investigate the relationship between corporate reputation and intention towards food innovation, along with the other components of Theory of Planned Behaviour model, with an extension of social media engagement in the context of India and the US. Their samples confirm that social media engagement has an impact on creating intention to purchase innovative food products, subjective norms and perceived behavioral control. In particular, they introduce a holistic perspective to innovative food purchasing by incorporating all the elements of the new food, such as the role of corporate reputation, subjective norms, perceived behavioral control and social media engagement. They conclude that the marketing of innovative food products must leverage on the role of social media and must engage in popular digital platforms such as Facebook, YouTube and Instagram.

The sixth article, "A holistic framework of corporate website favourability", by Ageeva, Foroudi, Melewar, Nguyen and Dennis, offers a comprehensive understanding of corporate website favorability (CWF). It examines the influence of CWF on corporate image, corporate reputation, loyalty and identification. The authors provide an extensive review of previous corporate websites studies from the perspectives of marketing, management, corporate identity and corporate visual identity, and offer a conceptual understanding of the antecedents and consequences of CWF, which future research could empirically test. In particular, they provide an approach by which a corporation can design and manage a favorable corporate website. They explain that, owing to advances in internet technology, there is a tendency for a unique corporate website to be designed for customers in order to gain a competitive advantage, as this helps in integrating marketing communication strategies, improving customer relationships and increasing loyalty. They conclude that it is crucial for successful e-businesses to develop a favorable website that takes the design aspect into consideration, to ensure customer expectations are met.

The final article, "A review of e-mass customization as a branding strategy", by Yan, Gupta, Schoefer and Licsandru, explores how e-mass customization brand strategies are implemented, involving the design of a web interface, modularity-based manufacturing and enabling technologies within a company. In particular, their paper identifies two typologies of e-mass customization based on the degrees of customer co-design in the process: collaboration-based customization, which involves customers at an early stage and promises major revisions to the product; and adoption-based customization, which brings customers into the post-design stage and offers segmented revisions. The study notes that as brands become more buyer-centric, e-mass customization (which combines mass- and custom-made production processes) can be specialized to each consumer; this can be seen as a viable and effective way to generate customer purchase intention and brand loyalty. The authors offer a brand strategy of e-mass customization through an extensive literature review; explore the impact of the e-mass on brand performance and brand loyalty; and conclude by illustrating this strategy in a conceptual model. Their paper contributes to the marketing and branding literature by planning strategic methods to incorporate customer involvement in customizing products.

We hope all these articles will encourage further discussion and debate as the digital and technology era advances further. For example, future empirical work could help to clarify how and when to use co-creation, its impact on corporate reputation, and which digital platforms are best for engaging with particular consumer and stakeholder groups in the digital society. Understanding these issues more fully is key to improving overall marketing and communication strategies.

\section{References}

Belk, R.W. 2013. Extended self in a digital world. Journal of Consumer Research 40 (3): 477-500.

Biraghi, S., and R.C. Gambetti. 2013. Corporate branding: Where are we? A systematic communication-based inquiry. Journal of Marketing Communications 3: 1. https://doi.org/10.1080/13527 266.2013.768535.

Cova, V., and B. Cova. 2002. Tribal marketing: The tribalisation of society and its impact on the conduct of marketing. European Journal of Marketing 36 (5-6): 595-620.

Fombrun, C.J., and C. Van Riel. 1997. The reputational landscape. Corporate Reputation Review 1 (1): 5-13.

Gensler, S., F. Völckner, Y. Liu-Thompkins, and C. Wiertz. 2013. Managing brands in the social media environment. Journal of Interactive Marketing 27 (4): 242-256.

Groß, M. 2015. Mobile shopping: A classification framework and literature review. International Journal of Retail and Distribution Management 43 (3): 221-241.

Hamzah, Z.L., S.F.S. Alwi, and M.N. Othman. 2014. Designing corporate brand experience in an online context: A qualitative insight. Journal of Business Research 67 (11): 2299-2310. 
Hietanen, J., and J. Rokka. 2015. Market practices in countercultural market emergence. European Journal of Marketing 49 (9/10): $1563-1588$.

Kang, J.-Y.M., J.M. Mun, and K.K. Johnson. 2015. In-store mobile usage: Downloading and usage intention toward mobile locationbased retail apps. Computers in Human Behavior 46 (May): 210-217.

Kline, S., N. Dyer-Witheford, and G. De Peuter. 2003. Digital play: The interaction of technology, culture, and marketing. Montreal: McGill-Queen's Press-MQUP.

Maitlis, S., T.J. Vogus, and T.B. Lawrence. 2013. Sensemaking and emotion in organizations. Organizational Psychology Review 3 (3): $222-247$.

Melewar, T.C., M. Gotsi, and C. Andriopoulos. 2012. Shaping the research agenda for corporate branding. European Journal of Marketing 46 (5): 600-608.

Olins, W. 2014. Wally Olins Brand New: The shape of brands to come. New York: Thames and Hudson.

Park, H., and Y.K. Kim. 2014. The role of social network websites in the consumer-brand relationship. Journal of Retailing and Consumer Services 21 (4): 460-467.

Prahalad, C.K., K. Koimbratore, and V. Ramaswamy. 2004. Co-creation experiences: The next practice in value creation. Journal of Interactive Marketing 18 (3): 5-14.

Raithel, S., and M. Schwaiger. 2015. The effects of corporate reputation perceptions of the general public on shareholder value. Strategic Management Journal 36 (6): 945-956.

Riva, C. 2010. Social network. Bologna: Società Editrice Il Mulino.

Schultz, D.E., and M.P. Block. 2011. Understanding customer brand engagement behaviors in today's interactive marketplace. Micro and Macro Marketing 20 (2): 227-244.

Schwaiger, M. 2004. Components and parameters of corporate reputation-An empirical study. Schmalenbach Business Review 56 (1): 46-71.

Sillence, E., and C. Baber. 2004. Integrated digital communities: Combining web-based interaction with text messaging to develop a system for encouraging group communication and competition. Interacting with Computers 16 (1): 93-113.

Vargo, S.L., P.P. Maglio, and M.A. Akaka. 2008. On value and value co-creation: A service systems and service logic perspective. European Management Journal 26 (3): 145-152.

Walker, K. 2010. A systematic review of the corporate reputation literature: Definition, measurement, and theory. Corporate Reputation Review 12 (4): 357-387.

Publisher's Note Springer Nature remains neutral with regard to jurisdictional claims in published maps and institutional affiliations.

Sharifah Faridah Syed Alwi $\mathrm{PhD}$ is a Reader in Corporate Brand Management at Brunel Business School, Brunel University London. She has a PhD from Manchester Business School, UK. Her research works have appeared in the British Management Journal, Business Ethics Quarterly, International Marketing Review, Journal of Business Research and European Journal of Marketing. Her main research interest is branding at different levels and entities which include product, digital, corporate and institution.
T. C. Melewar PhD HFAM is Professor of Marketing and Strategy at the Business School, Middlesex University London, UK. Prior to joining Middlesex in 2013, he was Professor at Brunel University, UK and Zurich University of Applied Sciences (ZHAW) in Switzerland. He also has held academic positions at University of Warwick (Warwick Business School) and De Montfort University in the UK and MARA Institute of Technology, Malaysia. TC's research interests include corporate identity/branding and international marketing strategy. $\mathrm{He}$ has published over 150 journal articles in academic journals such as, the Journal of International Business Studies, International Marketing Review, European Journal of Marketing, Journal of World Business, Industrial Marketing Management, Journal of Business Research, International Journal of Market Research and International Journal of Advertising among many others. He has written eight books in the areas of corporate branding/identity and international marketing with publishers such as Routledge, Emerald and Palgrave. He was the former Editor-in-Chief of the Journal of Brand Management. Now, he is the Editor Emeritus of this journal. He is also on the Editorial Advisory Board for the following journals: Journal of Marketing Communications, Corporate Reputation Review, Marketing Intelligence and Planning, and Corporate Communications: An International Journal. He is also the Founder and Chair of the following colloquia, Place Branding and Management; Design, Branding and Marketing; and Corporate Branding, Identity, Image and Reputation (COBIIR). TC is an Honorary Fellow of the Academy of Marketing, awarded in 2016.

Maria Teresa Cuomo $\mathrm{PhD}$ is an Associate Professor of Business Economics at the University of Salerno, where she teaches "Management and Innovation" and "Management". She teaches also at the Business School of the 'Bicocca' University in Milan. She is Member of several Editorial Committees of national and international journals. She has published in top international journals, about: reputation, consumer behavior, augment retail, corporate and investment assessment. She has presented papers and research outcomes at numerous Conferences all around the world. She carries out research, consultancy, and training to various organizations (both public and private) on finance and performance, investment assessment, market research, and marketing.

Manfred Schwaiger PhD is Full Professor of Business Administration, Head of the Institute of Market-Based Management (IMM), and Dean of Studies at the Munich School of Management within Ludwig-Maximilians-University in Munich (LMU), for which he has been serving as a Dean from 2003 to 2005 . His main research interests cover the management of intangible assets (esp. reputation and trust), return on marketing, consumer behavior, corporate communications, and market and trend research. His academic work has been published in leading journals in the field (e.g. Strategic Management Journal), and has been awarded with a number of best paper awards. Manfred Schwaiger has been a Member of the Board of Directors of the German Academic Association for Business Research (VHB), and he still serves as a Member of the International Advisory Board of EMLyon, Grande École. Moreover, Manfred has been serving as a Consultant to several Blue Chip Companies in Germany and the US, among others to Allianz and AXA insurance in the fields of new product development, strategic management and trust building. 